\title{
JOHN WESLEY AS A PUBLIC THEOLOGIAN: THE CASE OF THOUGHTS UPON SLAVERY
}

\author{
David N Field \\ Research Institute for Theology and Religion \\ University of South Africa \\ Academic Co-ordinator \\ Methodist e-Academy, Switzerland
}

\begin{abstract}
Public theology has become an important mode of theological engagement in secular and pluralistic contexts yet there is debate as to the character of this engagement. This article argues that an analysis of the nascent public theology developed by John Wesley can contribute to the development of a prophetic public theology. This nascent prophetic public theology is best demonstrated in his booklet Thoughts upon Slavery. Wesley's argument is critically analysed in the context of eighteenth century Britain. On the basis of this analysis eight propositions for a prophetic public theology are developed.
\end{abstract}

Key Words: John Wesley; Slavery; Public Theology; Prophetic Theology; Methodist Theology

Public theology can be defined as the theological engagement in public conversation and debate within a pluralistic society in order to contribute "to the formation of personal decisions and collective policy-making in economic, political, religious and social realms." This definition hides considerable debates as to the nature of the theological contribution, the public that is addressed, and the goals of that contribution. ${ }^{2}$ One approach to addressing these issues is to examine examples of pubic witness critically.

John Wesley, an eighteenth century evangelist and holiness preacher, may not appear to be an obvious example of a public theologian. Methodism has, however, been characterised by an engagement with society which can in part traced back to Wesley. Moreover, between 1768 and 1778 Wesley published a number of pamphlets addressing public issues such as poverty, the American Revolution, liberty, political power and the slave trade. ${ }^{3}$ While these pamphlets use some theological argument they include broader, non religious, arguments. Further the public sphere as a location of discourse and debate emerged in seventeenth and eighteenth century England. Wesley's pamphlets can be interpreted as nascent public theology.

Sebastian CH Kim, Theology in the Public Sphere, London: SCM, 2011:3.

See for example Kim, Theology, 3-26, and Dirkie Smit, "What does 'Public' mean? Questions with a View to Public Theology" in Len Hansen (ed.), Christians in Public: Aims, Methodologies and Issues in Public Theology. Stellenbosch: SUN, 2007:11-46, and John De Gruchy, "Public Theology as Christian Witness: Exploring the Genre" International Journal of Public Theology 1.1 2007:26-41.

3 These texts can be found in John Wesley, The Works of the Rev. John Wesley, MA, (ed.) by Thomas Jackson, Grand Rapids: Baker Book House, 1979, vol. 11. 


\section{Wesley's Thoughts upon Slavery - An Example of Eighteenth Century Public Theology}

Wesley's pamphlets attempted to influence public opinion with the aim of fostering a society characterised by justice, mercy and truth. While some appear to be misdirected and problematic, his 1774 booklet Thoughts upon Slavery was not only influential but provides a thought-provoking example of his nascent public theology. Its significance for the contemporary contexts is intensified in that it addresses an early manifestation of globalisation which continues to impact upon contemporary societies.

\section{Wesley's Context ${ }^{4}$}

The complex intertwining political and religious factors unleashed by the English Reformations led to two centuries of political instability prior to Wesley; there had been a civil war, the establishment of a republic which became a dictatorship, the re-establishment of the monarchy, the Glorious Revolution which replaced James II with William and Mary and a number of unsuccessful uprisings to restore the house of Stuart to the throne.

Arising out of these events was the growing entrenchment of "English Liberties" freedom of speech, freedom from arbitrary arrest, freedom of the press, increasing tolerance of confessional differences, the right to one's private property, the growing power of parliament and the limiting of the authority of the king. The pre-eminent legal scholar of the time, William Blackstone, argued that English law had become a system directed towards the protection and promotion of liberty. "Liberty" had become integral to English national identity even while its meaning and significance was debated. In the 1760 s these debates became increasingly contentious within England and America resulting in civil unrest which in America culminated in the American Revolution. It is probable that this growing contention about liberty provided the catalyst for Wesley to enter the public debate.

England was no democracy; its constitution balanced the powers of the King, the House of Lords and the House of Commons. The House of Commons was elected by a small minority of the population. Patronage, nepotism and other forms of corruption were rife. There were no uniform qualifications to vote but the basic requirements were that one had to be male, over 21 , and own property. The exception to the requirement of property ownership was to be found in Oxford and Cambridge where all graduates of the universities, and hence John Wesley, had the right to vote. Many members of the House of Commons had close links to members of the House of Lords either through family relationships or patronage. The king chose his own ministers and was not required to choose a ministry that had the support of the majority in parliament. At the time of Wesley's public interventions there was considerable tension between parliament and the ministries selected by George III.

Since the Reformation it had become common in England to write and distribute pamphlets and address religious and political themes. In 1695 the Licensing Act, which had

Detailed information on Wesley's context can be found in: HT Dickson (ed.) A Companion to Eighteenth Century Britain, Malden: Blackwell, 2002; Douglas Hay and Nicholas Rogers, Eighteenth Century English Society, Oxford: Oxford University Press, 1997; Paul Langford, A Polite and Commercial People: England 1727-1783, Oxford: Clarendon, 1989; Paul Kléber Monod, Imperial Island: A History of Britain and its Empire 1160-1837, Chichester: Wiley-Blackwell, 2009 and Roy Porter, English Society in the Eighteenth Century, London: Penguin, 1991.

5 See William Blackstone, Commentaries on the Laws of England: Facsimile of the First edition 1765-1769, Volume 1, Of the Rights of Persons, Chicago and London: University of Chicago Press, 1979:6, 7, 119-125. 
regulated the printing industry and publications, lapsed. The result was an explosion in the print media, newspapers were established and a vast array of pamphlets and books were published. The eighteenth century saw an increase in literacy so that the reading public was extended to include many people in the urbanised lower classes. Despite the limitations on voting rights and the restriction of parliamentary membership to communicants of the Church of England; eighteenth century Britain was characterised by widespread discussion of political and social themes fuelled by the flood of literature. This discussion was located in debating societies, gentlemen's clubs, political clubs, coffee houses and taverns. Moreover, towards the middle of the eighteenth century there was an increase in extraparliament politics. Non-voters were mobilised to influence parliament through various forms of support for candidates during elections; through protests and mass action, and through petitions. The enormous national debt gave considerable power to the emerging merchant classes who owned government bonds and who were not always represented directly in parliament. It was this nascent public sphere - deeply divided by class, status and power - that Wesley addressed in his pamphlets.

\section{A Brief Summary of Thoughts upon Slavery ${ }^{6}$}

Wesley's Thoughts upon Slavery provided a clear and concise argument against slavery as an institution. While he made extensive use of the work of others, notably that of the Quaker Anthony Benezet, ${ }^{7}$ the ethical core of the argument is Wesley's own. ${ }^{8}$ Wesley sought to refute the arguments of the defenders of slavery and to argue positively that slavery, and not just practices associated with it, was inherently unjust and immoral.

He began with an idealized description of Africa before the disruption of the slave trade based on the reports of explorers and traders. He argued that the African societies were characterised by justice, peace, prosperity, equity and reverence for God. The people were cultured, honest, rational and friendly. Wesley attributed these positive features to the worship of God either in Islam or African traditional religion.

He provided a description of the cruelties of slavery and the slave trade. He made the brief theological point that such suffering could not be the intention of the Creator and described the blood of the slaves as crying out to God. He described slave rebellions as the enslaved people "asserting their native liberty, which they have as much right to as to the air they breathe". 9

Wesley developed his ethical argument against the institution of slavery itself and not just its associated practices as it could not be reconciled with justice and mercy. This was a response to arguments that while the slave trade was evil and that slaves were treated cruelly, the institution was not inherently evil and could be implemented justly. He began his argument that the institution of slavery is inherently evil by explicitly setting "the Bible out of the question" 10 and developed an argument from natural law and natural liberty. He argued the following:

Thoughts upon Slavery, in Wesley, Works (Jackson), vol. 11:59-79.

See Iva A Brendlinger, Social Justice through the Eyes of Wesley: John Wesley's Theological Challenge to Slavery, Ontario: Joshua, 200:19-33 and To be Silent ... would be Criminal: The Antislavery Influence and Writings of Anthony Benezet, Pietist and Wesleyan Studies, No 20, Lanham: Scarecrow, 2007.

$8 \quad$ For details of the sources see Frank Baker, “The Origins, Character and Influence of John Wesley's Thoughts upon Slavery" in Methodist History 22 1984:75-86.

$9 \quad$ Wesley, Thoughts upon Slavery $\$ 3: 8$ in Works (Jackson), vol. 11:68.

10 Wesley, Thoughts upon Slavery $\$ 4: 1$ in Works (Jackson), vol. 11:70. 
- Firstly, slave-holding as an institution is inconsistent with justice. Wesley argued that one cannot justly deprive someone of their natural liberty and hence all "slave-holding" is inconsistent with natural justice. ${ }^{11} \mathrm{He}$ stated: "Liberty is the right of every human creature, as soon as he breathes the vital air, and no human law can deprive him of that right he derives from the law of nature." 12 Justice required that liberty must be given to all.

- Secondly, the cruelty involved in capturing and enslaving people as well as the treatment of enslaved people are inconsistent with mercy.

- Thirdly, he rejected the argument that slavery was an economic necessity, and even it if was this could not override the ethical demands of justice and mercy.

- Fourthly, he rejected the argument that it was necessary to mistreat slaves in order to make them work. He argued that Africans are naturally intelligent and what the owners described as their stupidity was a product of the system of slavery. Moreover, what the masters described as their stubbornness and wickedness was their response to their enslavement. He asked slave owners: "What wonder if they should cut your throat? And if they did, whom could you thank for it but yourself? You first acted the villain in making them slaves whether you stole them or bought them". ${ }^{13}$

- Finally he applied his argument to various groups of people involved in the slave trade.

\section{John Wesley's Non-Religious Argument}

What is striking about Wesley's argument is that, while the text contains numerous biblical allusions, he deliberately set the bible aside as the basis for his argument. This is even more significant when compared with numerous contemporary tracts written in support of and opposition to slavery. Appeals to biblical texts were significant components of most of their arguments ${ }^{14}$ and further biblical arguments appeared in the sources that Wesley used. ${ }^{15}$ Wesley's non-religious argument has two major components. The first is the description of African societies and the contrasting cruelties of the slave trade and slavery. The second is an argument based on natural law and liberty.

The descriptive dimension is based on what Wesley believed to be accurate eyewitness accounts and his own observations of slavery in America. This empirical argument made available the information about the realities of slavery and its consequences. This had three functions. Firstly, it described the phenomenon which was being ethically evaluated. Secondly, it falsified the understanding of slavery put forward by its supporters. Slavery was not an act of mercy on the part of slavers to deliver African prisoners of war from some

11 Wesley, Thoughts upon Slavery $\$ 4: 2$, Wesley draws upon William Blackstone's work to refute arguments that justified slavery as being compatible with natural law. See Blackstone, Commentaries, Vol. 1:411, 412.

12 Wesley, Thoughts upon Slavery 5.6 in Works (Jackson), Vol. 11:79.

Wesley, Thoughts upon Slavery 4:9 in Works (Jackson), Vol. 11:75.

14 See for example Samuel Seewall, The Selling of Joseph: A Memorial, Boston: Green and Allen, 1700; John Woolman, Considerations on the Keeping of Negroes, Philadelphia: Tract Association of Friends, 1754; A Pennsylvanian, An Address to the Inhabitants of the British Settlements in America, Upon Slave-Keeping, Philadelphia: John Dunlap, 1773; "An African Merchant", A Treatise upon the Trade from Great Britain to Africa, London: R Baldwin, 1772 and Thomas Thompson, The African Trade for Negro Slaves, Shown to be Consistent with the Principles of Humanity and the Laws of Revealed Religion, Canterbury: Simmons and Kirkby, [1772 ?].

15 See Benezet, A Short Account of the Part of Africa Inhabited by the Negros, and Some Historical Account of Guinea in Brendlinger, To be Silent, 123-135 and 137-204 and Granville Sharp, A Representation of the Injustice and Dangerous Tendency of Tolerating Slavery or of Admitting the Least Claim of Private Property in the Persons of Men in England, London: Benjamin Wright and Robert Horsfield, 1764. 
worse fate. ${ }^{16}$ Thirdly, as Wesley held that all knowledge was derived from experience, ${ }^{17}$ slavery was the reality that was experienced by slaves and as it was described by those who observed it. This contrasted with the arguments of slavery's supporters that cruelty was an aberration that could be reformed and that an ideal ethical slavery was possible. For Wesley there was no ideal form of slavery; the slavery that was to be evaluated ethically was the actually existing slavery as testified to by eyewitnesses. Moreover he viewed slavery from the perspective of its impact on its victims and not its beneficiaries.

The argument based on natural law and natural liberty is best understood as a strategic move designed to widen the appeal he is making. This can be seen from three perspectives. Firstly, the discourse of natural rights and natural law had, under the influence of Grotius, Locke, Hume and others, become the dominant intellectual discourse for discussing the organisation of human society. Wesley's argument would have resonated with the educated elite in a way that a simple appeal to the Bible would not have done. Secondly, this discourse had not remained the property of the elite but had become integral to English national identity. In the political unrest that characterised the decade in which Wesley wrote the rallying cry of opposition to the political establishment was liberty. Wesley had sensed the mood of the time. Thirdly, paradoxically, issues of liberty and natural rights had been central to a debate within the slave trade from the time of the Glorious Revolution. This was not in relation to the liberty and rights of the slaves but to the liberty and rights of the traders. The Royal African Company had been given a royal charter guaranteeing it the exclusive right to trade with the African continent. This right was challenged by independent traders who wanted a part in the lucrative slave trade. They appealed to parliament against the prerogatives given by an absolute monarch on the basis of the English liberties - that is that every English person had the right to engage in trade and hence in the buying and selling of Africans. ${ }^{18}$ Wesley's argument is that Africans have the same right to liberty as the English.

The appeal to natural rights and liberty was not uncontested. Significant natural law thinkers who in general rejected slavery made exceptions: Hugo Grotius accepted the validity of selling oneself into slavery and John Locke affirmed the legitimacy of slavery for prisoners of war. ${ }^{19}$ Some pro-slavery writers argued that while Africans had natural liberty it was legitimately taken from them as a punishment for criminality or as a consequence of war. ${ }^{20}$ Many Americans, as Wesley noted, who justified their demand for independence by an appeal to natural liberty, practiced slavery. ${ }^{21}$

The argument based on the empirically determined cruelties and injustices of slavery and the appeal to natural law and liberty led to a surprising radicalisation of Wesley's position. Wesley was a political conservative who strongly criticised political mass action, rejected democracy and feared a return to political chaos. ${ }^{22}$ Here, however, he legitimated

16 Wesley, Thoughts upon Slavery 4.4, Works (Jackson) 11:71; compare Thomson, African Trade 21 \& 25-26.

17 For details of Wesley's empiricism see Timothy J Crutcher, The Crucible of Life: The Role of Experience in John Wesley's Theological Method, Lexington: Emeth, 2010.

18 See William A Pettigrew, Freedom's Debt: the Royal African Company and the Politics of the Atlantic Slave Trade, 1672-1752, Chapel Hill: University of North Carolina Press, 2013.

19 See Stephen Buckle, Natural and the Theory of Property: Grotius to Hume, Oxford: Clarendon, 1991:47-52, 167-168, 178-179, 289-290.

20 See, for example, Thompson, The African Trade, 23-31.

21 See his discussion in A Calm Address to our American Colonies, Works (Jackson), Vol. 11:81.

22 See Theodore R Webber, Politics in the Order of Salvation: Transforming Wesleyan Political Ethics, Nashville: Kingswood, 2001:41-388. 
slave resistance and rebellion as an expression of natural liberty in contradiction of biblical injunctions to slaves and in a context in which slave rebellions were regular occurrences.

\section{Wesley's Continuing Response to Slavery ${ }^{23}$}

Wesley's contribution to the struggle against slavery did not end with the publication of Thoughts upon Slavery - he continued to condemn slavery as the major sin of the British nation. He became a supporter of the Society for Abolition of the Slave Trade when it was founded in 1787. He used the Arminian Magazine - which he published as a means of instructing and encouraging his followers - to persuade Methodists to oppose slavery, to support the Society for the Abolition of the Slave Trade, and to petition parliament to end slavery. In a short and cryptic letter to one of his travelling preachers, Henry Moore, he referred to a note that Moore had sent to the other preachers with the statement: "I would do anything that is in my power toward the extirpation of that trade which is a scandal not only to Christianity but humanity." ${ }^{24}$ Presumably the note encouraged the preachers to oppose slavery. Symbolically the last letter he wrote before his death was to William Wilberforce supporting him in his struggle to have the slave trade abolished.

\section{The Theological Roots of Wesley's Public Theology}

While Wesley's writings addressing public issues are small in number and come from a relatively short period in his life, they are deeply rooted in two key aspects of his theology.

The first aspect is his theology of sanctification. The pursuit and promotion of holiness was central to Wesley's understanding of his vocation and that of Methodism. The central dynamic of Wesley's theology was that human beings were created in the moral image of God; the moral image had been destroyed as a consequence of the fall, and God was now at work restoring the moral image in human beings who responded in faith to the gospel. This restoration of the moral image is sanctification. The moral character of God is love and hence God created human beings to be characterised by love. Human beings who encounter God's love in Christ enter into a path of transformation through which their lives become increasingly characterised by love for God and neighbours (friends, strangers and enemies). 25 This transformation had two dimensions. The first is the transformation of inner attitudes, character and motivations. The second is concrete action which Wesley regularly described with the triad of "justice, mercy and truth". ${ }^{26}$ To be transformed by the Spirit into the moral image of God is to lead a lifestyle characterised by "justice, mercy and truth". Wesley's argument against slavery is rooted in an appeal to these virtues. Hence the struggle against the slave trade is a concrete expression of holiness in the face of the injustice, cruelty and deception of slavery.

The second theological root of Wesley's engagement with public issues is his theology of prevenient grace. ${ }^{27}$ Wesley held that as a consequence of the fall, all human beings have

23 Details of Wesley's continuing involvement in the struggle can be found in Brendlinger, Social Justice, 33-43, 147-170 and Warren Thomas Smith, John Wesley and Slavery, Nashville: Abingdon, 1986:104-112.

25 See Harald Lindström, Wesley and Sanctification: A Study in the Doctrine of Salvation, Nappanee: Francis Asbury, 1996 and David B McEwan, The Life of God in the Soul: The Integration of Love, Holiness and Happiness in the Thought of John Wesley, Milton Keynes: Paternoster, 2015.

26 See for example his sermon "On Former Times" in The Works of John Wesley (Bicentennial Edition), Vol. 3 , Sermons III: 71-114, Nashville: Abingdon, 1986:448.

27 For details of Wesley's theology of prevenient grace see Randy L Maddox, Responsible Grace: John Wesley's Practical Theology 1994:83-93, Kenneth J Collins, The Theology of John Wesley: Holy Love and the Shape of 
lost the moral image of God and are pervasively affected by sin. However, as an outworking of the universal consequences of the death of Christ, the Spirit is at work in all human beings, countering the consequences of sin; restoring moral accountability; providing knowledge of God's moral requirements of justice, mercy and truth, and enabling them to respond to God. As a consequence all human beings, regardless of religion or culture, are enabled to practice to varying extents justice, mercy and truth. Human ability to do so is dependent upon human response to God's grace. Positive responses lead to an upward spiral of greater achievements of justice, mercy and truth while persistent rejection of God's grace leads to a negative spiral. On the basis of his understanding of prevenient grace Wesley could address people within the public sphere, regardless of whether or not they were professing Christians, in the expectation that God was at work and would enable people to respond to the call for justice, mercy and truth.

\section{Wesley and Contemporary Public Theology}

Wesley's incipient public theology is more than an item of historical interest as his writings continue to have an influence on global and South African Christianity through the churches of the Methodist and Wesleyan tradition. Hence a critical re-examination of his incipient public theology in dialogue with contemporary debates can contribute to reflection on the public witness of churches within this tradition. Moreover, while Wesley's intervention against slavery is not without its problems, it makes an important contribution to the discussion of the public witness of the church which transcends denominational identity. It models an approach to the public witness of the church which has affinity with both public theologies, as they have emerged in North America and Europe, and the prophetic critique of society found in South African struggle theologies. Hence it suggests the mode of a prophetic public theology.

\section{Toward a Prophetic Public Theology with John Wesley}

Wesley's diverse political and public interventions are occasional responses to particular issues and contain a variety of affirmations and perspectives with different theological roots that in some cases complement each other but in others stand in tension, contrast and even contradiction to each other. Not all of these writings contribute to the development of a prophetic public theology, hence the focus of the following discussion is on his response to slavery and we will relate this to some of his other writings. The examination of his intervention against slavery gives rise to five propositions which describe the contours of a prophetic public theology.

Firstly, Wesley's intervention had a clear theologically rooted goal. This goal was twofold. The broad goal was the establishment of a society characterised by "justice, mercy and truth". This triad recurs regularly as an ethical norm in Wesley's writings which evaluated contemporary national and social issues. ${ }^{28}$ It summed up, for Wesley, God's moral requirements for inter-human relationships. Importantly for Wesley its presence in society was theologically grounded in his understanding of the moral character of God described in the Bible and in the universal influence of prevenient grace. This triad of virtues transcends particular forms of society and government; critiquing all social projects and acting as a lure drawing them to fuller embodiments of them. As a consequence it

Grace, Nashville: Abingdon, 2007, J Gregory Crofford, Streams of Mercy: Prevenient Grace in the Theology of John and Charles Wesley, Lexington: Emeth, 2010.

28 See for example the sermon "The Mystery of Iniquity", John Wesley: The Works of John Wesley (Bicentennial Edition), vol. 2, Sermons II:34-70, Nashville: Abingdon, 1985:467-468. 
displays a relative freedom from and a critique of the project of modernity which was emerging in Wesley's time. Moreover, these virtues were independent from the religious affiliation or lack of affiliation of a given society. The promotion of this triad was thus not directly linked to the promotion of Christianity and as he argued in Thoughts upon Slavery, they were often absent from societies which profess allegiance to Christianity and present in societies dominated by other religions.

Wesley moved beyond affirmation and promotion of this broad goal to a narrower concrete goal which was the eradication of what was for him the most significant violation of justice, mercy and truth in British society - the slave trade. It may have been possible to develop a social consensus around the values justice, mercy and truth; and the obviousness of Wesley's references to this triad suggests its broad public acceptance. However, the move from the obviousness of moral consensus to concrete violation of this consensus in slavery exposed the fractured character of society and the entrenched interests of the beneficiaries of slavery. It is precisely this concretisation in relation to a particular issue that challenged the society to fuller embodiments of these virtues. This dual goal gives rise to the first proposition: Prophetic public theology includes both a theologically-rooted vision for society that can be shared by the majority of its members and the penetrating critique of its specific failure to implement this vision.

Secondly, by virtue of his family heritage and education Wesley was a member of the social elite. His Oxford education provided him with social status, intellectual skills and the right to vote. However, when he addressed the issue of slavery he not only spoke on behalf of excluded and oppressed people but in significant ways he portrayed slavery and its consequences from their perspective. He used his social and educational privileges to give voice and visibility to those who were absent and excluded from the public sphere which discussed and presided over their fate. Within the contest of diverse and contradictory knowledge claims Wesley, probably unconsciously, opted to hear and articulate the cry of the victims. This standing in solidarity with the excluded and the victims is present in some of Wesley's other writings, notably in his Thoughts on the Present Scarcity of Provisions where he addressed poverty. ${ }^{29}$ Paradoxically, it is also present in his critique of the American struggle for independence, where he argued that the oppressed in America were not the middle class settlers calling for independence but the enslaved Africans. ${ }^{30}$ It is, however, missing from his writings dealing with political reform in Britain. ${ }^{31}$ The recognition that the public sphere is fractured and exclusive, and in many cases society's victims are invisible and absent from the public sphere, confronts public theology with the challenge of standing in solidarity with the excluded and the victims, and in doing so it conflicts with those who benefit from the exclusion and exploitation of others. Hence the second proposition: A prophetic public theology stands in solidarity with the victims, the excluded and silenced; it hears their cry, and attempts to articulate this voice in the public sphere addressing issues from their perspective and is thus brought into conflict with the beneficiaries of the status quo.

Thirdly, Wesley's critique of slavery is rooted in a description and a limited historical analysis of African society, the slave trade and the cruelties experienced by enslaved people. His analysis is characterised by a naive empirical realism which assumed that the honest witness reports the truth. His acceptance of these witnesses was undoubtedly

\footnotetext{
See Wesley, Works (Jackson), vol. 11:53-59.

30 See his A Calm Address to out American Colonies, in Works (Jackson), Vol. 11:80-90.

31 See Thoughts upon Liberty and Thoughts Concerning the Origin of Power in Works (Jackson), Vol. 11:34-53.
} 
influenced by his personal observation of slavery and interaction with enslaved people while he was in America. However, advocates of slavery also appealed to their experience and to the testimony of others. The anonymous author of Slave Trade: The Negro and the Freeborn Britain Compared or a Vindication of the Slave Trade claimed: "I was a merchant and ship owner of 24 years, during which time I gained no small share of experimental knowledge in the trade". ${ }^{32}$ They argued that slaves were prisoners of war or criminals; that the conditions under which they were transported and worked were humane, and that while mistreatment might occur this was the exception. ${ }^{33}$ Supporters of slavery questioned the accuracy of Wesley's "facts" about African cultures and those of Anthony Benezet whose work he used. ${ }^{34}$ In a later letter written to Samuel Hoare, one of the founding members of the Society for the Abolition of the Slave Trade, Wesley warned that the pro-slavery forces would "employ hireling writers" to support slavery. ${ }^{35}$ Wesley had moved from the naive expectation that his analysis of slavery would be accepted because it was based on eyewitness accounts, to the recognition, to some extent, of the contested character of knowledge. Since Wesley the sociology of knowledge has uncovered the numerous ways in which a person's social location, material interests, ideological presuppositions, cultural background and numerous other factors influence knowledge production. The third proposition is a prophetic public theology based on a thorough analysis of the issues, that is fully aware of the contested character of human knowledge

Fourthly, Thoughts upon Slavery provides a model of addressing an issue in nonreligious language in a way that resonated deeply with his context. This is in striking contrast to Wesley's sermons addressed to his followers, which are filled with religious and biblical arguments. Appeals to biblical authority also appear in his other political writings but here they are absent; Wesley chose to use the concepts of liberty and natural law. This choice is significant for, on the one hand, the language of civil liberties and natural rights was a dominant form of public discourse and had become an integral part of British national identity. Political debates revolved, not around the acceptability of the discourse of liberty, but on its application to specific cases. On the other hand, it resonated with fundamental aspects of Wesley's theology. Fundamental to his theological anthropology and soteriology was his understanding that human beings are responsible and accountable to God for their actions, their lives, their bodies and their possessions. While human freedom to act has been devastated by sin, prevenient grace restores to all human beings the ability to live and act responsibly. Hence all human beings have the responsibility and the right to make decisions about their own lives before God. No human institution has the right to take this away. Hence no human institution has the right to constrain human liberty. ${ }^{36}$ Wesley's theological account of liberty differed substantially from the various philosophical accounts that were common in the seventeenth and eighteenth century. In

32 Slave Trade. The Negro and the Freeborn Britain Compared or a Vindication of the Slave Trade Proving that it is Lawful and Right in a Religious, in a Political, and in a Commercial View, London: J Stockdale, J Straham, M Folingsby, J Johnson and W Richardson, [1789 ?]), the emphasis is in the original.

34 With regard to Benezet see An African Merchant, A Treatise, 30-33 and to Wesley the anonymous A Supplement to Mr Wesley's Pamphlet Entitled Thoughts upon Slavery, London: H Reynell, 1774.

35 Wesley, Letters, vol. 8:275.

36 See Weber, Politics, 303-352; Theodore Runyon, The New Creation: John Wesley's Theology for Today, Nashville: Abingdon, 1998:170-184; Leon O Hynson, “Wesley's 'Thoughts Upon Slavery': A Declaration of Human Rights" in Methodist History 33:1 1994:46-57, and "Human Liberty as Divine Right" A Study in the Political Maturation of John Wesley" in Journal of Church and State 25:1 (1983), 57-85, and Collins, Theology of John Wesley, 267-270. 
these accounts natural rights were rooted in understandings of what inherently belongs to a person by virtue of the person being human. ${ }^{37}$ In contrast, Wesley's account arises out of his understanding of humanity created in the image of God and therefore being responsible to God. Hence while their theoretical roots were different there was sufficient commonality at the level of policy to argue for a common praxis; this made cooperation possible in a pluralistic context. The fourth proposition is: A prophetic public theology adopts a discourse which resonates with both the public that is being addressed and with central theological convictions of the public theologian.

Fifthly, following the publication of Thoughts upon Slavery in 1774 Wesley continued to condemn slavery; he encouraged the early Methodists to do the same and later became an active supporter of political efforts to abolish slavery. Towards the end of his life his writings show an increasing awareness of the power of the political and economic forces that supported slavery. It is possible that this motivated him to move from public discourse to involvement in political action. Wesley's influence led the early Methodist movement to oppose slavery. In 1780, when the Methodist Episcopal Church was established in America it rejected slavery and instructed its members to free their slaves. ${ }^{38}$ After Wesley's death British Methodism maintained a tradition of opposing slavery despite a general policy of non-involvement in politics. ${ }^{39}$ Hence the fifth proposition is: A prophetic public theology combines involvement in public discourse with the praxis of social transformation.

\section{Toward a Prophetic Public Theology beyond John Wesley}

Wesley's public intervention against slavery has particular weaknesses and the development of a prophetic public theology in the tradition of John Wesley needs to take account of these and move beyond them. This moving beyond Wesley can be summarised in three further propositions.

Firstly, we noted above that Wesley's critique of slavery is based on an analytical description of slavery; he does not, however, provide any analysis of the place of slavery in the British economy nor of its place in the complex network of economic and political power structures. As a result his appeal at the end of the booklet is for personal conversion of people involved in the slave trade. He later recognises to some extent the power of the supporters of slavery and hence the need for political struggle. In contrast his Thoughts upon the Present Scarcity of Provisions contains an analysis of the structural causes of poverty as Wesley understood them, and thus the solutions he proposes are structural in character. ${ }^{40}$ Yet even here his analysis does not question the political status quo which ordered society to serve the interests of the wealthy landowners and the early capitalists. A prophetic public theology needs to move beyond Wesley in this respect. Hence the sixth proposition: A prophetic public theology must be rooted in a thorough social analysis of the network of power structures which shape a society exposing the relationships of exploitation, beneficence and oppression.

Secondly, Wesley dismissed the argument that the slave trade was necessary for England's economic prosperity arguing that such prosperity could not override the demands of justice, mercy and truth. While Wesley's rejection was clearly directed toward the

See Buckles Natural Law, 38-31, what belongs to someone is not private property as defined by positive law but refers to one's life, body and liberty. Legally defined private property is an extension of this; see.

38

See Warren, John Wesley, 112-117.

See Brendlinger, Social Justice, 158-170.

40 See Wesley, Works (Jackson), vol. 11:53-59. 
wealthy beneficiaries of slavery, the abolition of slavery would have had a major impact on the economy of England and hence on the working poor whose wellbeing was an important focus of Wesley's ministry. Wesley appears to show no awareness that his opposition to slavery entails a choice which has the potential to affect negatively other people who were poor and powerless; this maybe a consequence of the inadequacy of his social analysis. Intervention in complex societies requires making choices that can be defended yet which are often fraught with problems. This gives rise to the seventh proposition: A prophetic public theology involves making responsible choices in complex socio-economic contexts such choices are not without negative consequences.

Thirdly, in the texts that we have from Wesley there is no theological argument that articulates his understanding of liberty in the context of slavery or of how he correlated this with the relevant biblical texts. Moreover, while we can discern a link between his opposition to slavery and his understanding of holiness, in the light of his other writings, he does not make the connection explicit. Hence the relationship between his public theology and his church theology remained ambiguous. Later in the debates within American Methodism over slavery this was to prove a significant problem, as those who promoted the tolerance of slavery appealed to the Bible to support their arguments. ${ }^{41}$ This inadequacy in Wesley's theology highlights the importance of integrating public theology and church theology, political praxis and church praxis. Hence our final proposition is: When a prophetic public theology addresses the public sphere it must simultaneously address the church, demonstrating that what is being advocated in the public sphere is deeply rooted in the gospel.

\section{Conclusion}

Wesley's argument against slavery presents us with a nascent prophetic public theology. The seven propositions drawn from a critical engagement with his work are not a complete description of a prophetic theology but are presented rather as broad contours for the development of such a theology and as a stimulus to further reflection and development. The contemporary context in South Africa and globally is vastly different from eighteenth century England and hence the adequacy of these propositions, as well as their further development and supplementation must arise out of an engagement in public witness in our contemporary contexts.

\section{BIBLIOGRAPHY}

Anonymous 1789 (?). Slave Trade. The Negro and the Freeborn Britain Compared or a Vindication of the Slave Trade Proving that it is Lawful and Right in a Religious, in a Political, and in a Commercial View. J Stockdale, J Straham, M Folingsby, J Johnson and W Richardson, London.

Anonymous 1774. A Supplement to Mr Wesley's Pamphlet Entitled Thoughts upon Slavery. H Reynell, London.

A Pennsylvanian 1773. An Address to the Inhabitants of the British Settlements in America, Upon Slave-Keeping. John Dunlap, Philadelphia.

41 See Russel E Richy, Kenneth E Rowe and Jean Miller Schmidt, The Methodist Experience in America: A History, Vol.1, Nashville: Abingdon, 2010:175-196. 
An African Merchant 1772. A Treatise upon the Trade from Great Britain to Africa. R Baldwin, London.

Baker, F 1984. "The Origins, Character and Influence of John Wesley's Thoughts upon Slavery." Methodist History, Vol. 22:2:75-86.

Blackstone, W 1979. Commentaries on the Laws of England: Facsimile of the First Edition 1765-1769, Volume 1, Of the Rights of Persons. University of Chicago Press, Chicago and London.

Brendlinger, IA 2006. Social Justice through the Eyes of Wesley: John Wesley's Theological Challenge to Slavery. Joshua, Ontario.

Brendlinger, IA 2007. To be Silent ... would be Criminal: The Antislavery Influence and Writings of Anthony Benezet. Pietist and Wesleyan Studies, No 20, Scarecrow, Lanham.

Buckle, S 1991. Natural and the Theory of Property: Grotius to Hume. Clarendon, Oxford. Collins, KJ 2007. The Theology of John Wesley: Holy Love and the Shape of Grace. Abingdon, Nashville.

Crofford, JG 2010. Streams of Mercy: Prevenient Grace in the Theology of John and Charles Wesley. Emeth, Lexington.

Crutcher, TJ 2010. The Crucible of Life: The Role of Experience in John Wesley's Theological Method. Emeth, Lexington.

De Gruchy, J 2007. "Public Theology as Christian Witness: Exploring the Genre." International Journal of Public Theology, Vol. 1:1:26-41.

Dickson, HT (ed.) 2002. A Companion to Eighteenth Century Britain. Malden: Blackwell. Hay, D, Rogers, N 1997. Eighteenth Century English Society. Oxford University Press, Oxford.

Hynson, LO 1994. “Wesley's 'Thoughts Upon Slavery': A Declaration of Human Rights” in Methodist History 33:1:46-57.

Hynson, LO 1983. "Human Liberty as Divine Right" A Study in the Political Maturation of John Wesley" in Journal of Church and State 25:1: 57-85.

Kim, SCH 2011. Theology in the Public Sphere. SCM, London.

Langford, P 1989. A Polite and Commercial People: England 1727-1783. Clarendon, Oxford.

Lindström, H 1996. Wesley and Sanctification: A Study in the Doctrine of Salvation. Francis Asbury, Nappanee.

Maddox, RL 1994. Responsible Grace: John Wesley's Practical Theology. Kingswood, Nashville.

McEwan, DB 2015. The Life of God in the Soul: The Integration of Love, Holiness and Happiness in the Thought of John Wesley. Paternoster, Milton Keynes.

Monod, PK 2009. Imperial Island: A History of Britain and its Empire 1160-1837. WileyBlackwell, Chichester.

Pettigrew, WA 2013. Freedom's Debt: the Royal African Company and the Politics of the Atlantic Slave Trade, 1672-1752. University of North Carolina Press, Chapel Hill.

Porter, R 1991. English Society in the Eighteenth Century. Penguin, London.

Richy, RE, Rowe KE, Schmidt, JM 2010. The Methodist Experience in America: A History. Vol.1, Abingdon, Nashville.

Runyon, T 1998. The New Creation: John Wesley's Theology for Today. Abingdon, Nashville.

Seewall, S 1700. The Selling of Joseph: A Memorial. Green and Allen, Boston. 
Sharp, G 1764. A Representation of the Injustice and Dangerous Tendency of Tolerating Slavery or of Admitting the Least Claim of Private Property in the Persons of Men in England. Benjamin Wright and Robert Horsfield, London.

Smit, D 2007. "What does 'Public' mean? Questions with a View to Public Theology" in Len Hansen (ed.), Christians in Public: Aims, methodologies and Issues in Public Theology. SUN, Stellenbosch.

Smith, WT 1986. John Wesley and Slavery. Abingdon, Nashville.

Thompson, T 1772 (?). The African Trade for Negro Slaves, Shewn to be Consistent with the Principles of Humanity and the Laws of Revealed Religion. Simmons and Kirkby, Canterbury.

Webber, TR 2001. Politics in the Order of Salvation: Transforming Wesleyan Political Ethics. Kingswood, Nashville.

Wesley, J 1979. The Works of the Rev. John Wesley, M.A., ed. Thomas Jackson, Vol. 11. Baker Book House, Grand Rapids.

Wesley, J 1931. The Letters of John Wesley. edited by John Telford, volume 8, Epworth, London.

Wesley, J 1986. The Works of John Wesley (Bicentennial Edition). Vol. 3, Sermons III:71-11, Abingdon, Nashville.

Wesley, J 1985. The Works of John Wesley (Bicentennial Edition), Vol. 2, Sermons II:34-70. Abingdon, Nashville.

Woolman, J 1754. Considerations on the Keeping of Negroes. Tract Association of Friends, Philadelphia. 